\title{
WORK-FAMILY CONFLICT DENGAN DISIPLIN KERJA ANGGOTA POLRI DISTRIK WANADADI POLRES BANJARNEGARA
}

\author{
WORK-FAMILY CONFLICT WITH WORK DISCIPLINEPOLICE \\ MEMBERS OF WANADADI DISTRICT BANJARNEGARA POLRES
}

\author{
Oleh : \\ Faozi Jafar*) \\ Retno Dwiyanti **) \\ Pambudi Rahardjo ${ }^{* * * *}$ )
}

\begin{abstract}
ABSTRAK
Penelitian ini bertujuan untuk mengetahui hubungan work-family conflict dengan disiplin kerja anggota Polri Distrik Wanadadi Polres Banjarnegara.Populasi dalam penelitian ini adalah seluruh anggota Polri di Distrik Wanadadi Polres Banjarnegara yang meliputi wilayah kerja Polsek Banjarmangu, Wanadadi, Punggelan dan Polsek Rakit sebanyak 67 orang dan seluruhnya menjadi sampel penelitian. Metode pengumpulan data dilakukan dengan skala work-family conflict dan skala disiplin kerja. Hasil uji validitas skala work-family conflict bergerak dari 0,124 sampai dengan 0,665 dengan taraf signifikansi $5 \%(\alpha=0,05)$ atau interval kepercayaan 95\% dan $n=30$, maka diperoleh nilai $r_{\text {tabel }}=0,361$. Hasil uji validitas skala disiplin kerja bergerak dari -0,202 sampai dengan 0,760 dengan taraf signifikansi 5\% $(\alpha=0,05)$ atau interval kepercayaan 95\% dan $n=30$, maka diperoleh nilai $r_{\text {tabel }}=0,361$. Hasil uji validitas skala work-family conflict diketahui dari 50 aitem pertanyaan, terdapat 10 aitem yang tidak valid.Hasil uji validitas skala disiplin kerja diketahui dari 70 aitem pertanyaan, terdapat 14 aitem yang tidak valid.Item pernyataan yang tidak valid dibuang sehingga tidak diikutkan untuk mengambil data penelitian. Hasil uji reliabilitas skala work-family conflictsebesar 0,9381 dan untuk skala disiplin kerja sebesar 0,9482, yang berarti skala work-family conflict dan disiplin kerja reliabel.Hasil uji hipotesis menggunakan korelasi product moment diperoleh nilai $r$ hitung sebesar -0,485 dengan nilai $p=0,00$ yang lebih kecil dari $\alpha=0,05$, artinya terdapat hubungan work-family conflict dengan disiplin kerja anggota Polri Distrik Wanadadi Polres Banjarnegara.
\end{abstract}

Kata Kunci : Anggota polri, Disiplin kerja, Work-family conflict

\section{ABSTRACT}

This study aims to determine the relationship of work-family conflict with the work discipline of Polri District Police Sub-district of Banjarnegara.Populasi in this research is all members of Police in Wanadadi District Polres Banjarnegara which covers work area Polsek Banjarmangu, Wanadadi, Punggelan and Police Rakit 67 people and entirely into the research sample.

\footnotetext{
*) Alumni Fakultas Psikologi Universitas Muhammadiyah Purwokerto

** ) Dosen Fakultas Psikologi - Universitas Muhammadiyah Purwokero

*** ) Dosen Fakultas Psikologi - Universitas Muhammadiyah Purwokero
} 
Methods of data collection is done with work-family conflict scale and scale of work discipline. The result of the validity test of work-family conflict scale from 0.124 to 0.665 with significance level $5 \%(\alpha=0,05)$ or $95 \%$ confidence interval and $n=30$, hence $r_{-}$table $=0,361$. The results of the validity test of the scale of the work discipline move from -0.202 to 0.760 with a significance level of $5 \%(\alpha=$ 0.05 ) or 95\% confidence interval and $n=30$, then obtained $r$ tabel $=0.361$. The result of the validity test of work-family conflict scale is known from 50 question aitem, there are 10 invalid items. The test result of the work discipline scale scale is known from 70 question aitem, there are 14 invalid items. Invalid item statements are discarded so they are not included for take research data. The result of work-family conflicts test is 0.9381 and for work discipline scale is 0,9482, which means work-family conflict scale and work discipline reliabel.Hasil test hypothesis using product moment correlation obtained value r count equal to -0.485 with $p$ value $=0.00$ is smaller than $\square=0.05$, meaning there is a workfamily conflict relationship with work discipline of Police Sub-district of Wanadadi Polres Banjarnegara.

Keywords: Discipline work, Members of Police, Work Family Conflict

\section{PENDAHULUAN}

Kepolisian Indonesia pada dasarnya lahir bersamaan dengan Proklamasi Kemerdekaan Republik Indonesia.Secara formal Kepolisian Negara Republik Indonesia (POLRI) dibentuk bersamaan dengan pelantikan Kepala Kepolisian Negara Tanggal 29 September 1945. Paradigma baru Polri di era reformasi sejalan dengan visi bangsa Indonesia masa depan. Visi bangsa Indonesia masa depan dapat, yaitu : "Terwujudnya masyarakat Indonesia yang damai, demokratis, berkeadilan, berdaya saing, maju dan sejahtera dalam wadah Negara Kesatuan Republik Indonesia yang didukung oleh manusia Indonesia yang sehat, mandiri, beriman, bertaqwa, berakhlak mulia, cinta tanah air, berkesadaran hukum dan lingkungan, menguasai ilmu pengetahuan dan teknologi, memiliki semangat kerja yang tinggi serta berdisiplin.

Tugas pokok Polri sebagaimana tercantum dalam Undang-Undang Nomor 2 Tahun 2002 tentang Kepolisian Negara Republik Indonesia, yaitu: 1) Memelihara keamanan dan ketertiban masyarakat, 2) Menegakkan hukum dan 3) Memberi perlindungan, pengayoman dan pelayanan kepada masyarakat.

Untuk mewujudkan kondisi kamtibmas yang mantap, terkendali dan dinamis yang sejalan dengan tuntutan dan harapan masyarakat yang terus meningkat terhadap hak-haknya untuk menikmati keamanan, ketertiban dan ketentraman yang lebih baik, saat ini dan dimasa mendatang tidak semakin ringan.Hal yang demikian tidak terkecuali di Polres Banjarnegara.Untuk itu, seluruh anggota Polsek perlu memiliki sikap disiplin yang tinggi dalam menjalankan tugasnya. 
Disiplin merupakan sikap mental yang tercermin dalam perbuatan atau tingkah laku perorangan, kelompok atau masyarakat berupa ketaatan terhadap peraturan-peraturan atau ketentuan-ketentuan yang ditetapkan pemerintah atau etik, norma, dan kaidah yang berlaku dalam masyarakat untuk tujuan tertentu (Sinungan, 2000). Dalam Peraturan Pemerintah Republik Indonesia Nomor 2 Tahun 2003 Tentang Peraturan Disiplin Anggota Kepolisian Negara Republik Indonesia pada Pasal 1 angka 2 disebutkan bahwa disiplin adalah ketaatan dan kepatuhan yang sungguh-sungguh terhadap peraturan disiplin anggota Kepolisian Negara Republik Indonesia. Peraturaan perundang-undangan terkait dengan disiplin Polri diharapkan dapat menjamin kedisiplinan anggota Polri.Namun fakta yang ada di lapangan ternyata masih ditemui adanya pelanggaran disiplin oleh anggota Polri, khususnya di Polres Banjarnegara.

Disiplin kerja dapat didefinisikan sebagai suatu sikap menghormati, menghargai, patuh dan taat terhadap peraturan-peraturan yang berlaku, baik yang tertulis maupun tidak tertulis serta sanggup menjalankannya dan tidak mengelak untuk menerima sanksi-sanksinya apabila ia melanggar tugas dan wewenang yang diberikan kepadanya (Sastrohadiwiryo, 2001).

Menurut Gomes (2000) tujuan tindakan disiplin adalah untuk melindungi organisasi dari para anggota yang tidak produktif.Prosedur-prosedur pengaduan disatu pihak dikembangkanuntuk melindungi paraanggota terhadap alokasi yang tidak adil dari sanksi-sanksi dan imbalan-imbalan dari organisasi.

Peraturan disiplin anggota Kepolisian Negara Republik Indonesia tertuang dalam Peraturan Pemerintah Republik Indonesia Nomor 2 Tahun 2003 Tentang Peraturan Disiplin Anggota Kepolisian Negara Republik Indonesia. Peraturan pemerintah ini dengan jelas mengatur kewajiban yang harus ditaati dan larangan yang tidak boleh dilanggar oleh setiap anggota Kepolisian Negara Republik Indonesia yang melakukan pelanggaran disiplin.

Dalam Pasal 1 angka 4 dan 5 Peraturan Pemerintah Republik Indonesia Nomor 2 Tahun 2003 Tentang Peraturan Disiplin Anggota Kepolisian Negara Republik Indonesia disebutkan bahwa pelanggaran peraturan disiplin adalah ucapan, tulisan, atau perbuatan anggota Kepolisian Negara Republik Indonesia yang melanggar peraturan disiplin. Tindakan disiplin adalah serangkaian teguran lisan dan/atau tindakan fisik yang bersifat membina, yang dijatuhkan secara langsung kepada anggota Kepolisian Negara Republik Indonesia.

Data pelanggaran disiplin yang dilakukan oleh anggota Polri Distrik Wanadadi, sebagai berikut : 
Tabel 1. Data Pelanggaran DisiplinAnggota Polri Distrik Wanadadi Polres Banjarnegara Selama bulan Januari sampai Agustus 2014

\begin{tabular}{|c|c|c|c|c|}
\hline No & Tanggal & Jenis Pelanggaran & Ket & $\mathrm{Jml}$ \\
\hline 1 & 6 Januari & $\begin{array}{l}\text { Pasal } 4 \text { (d) PP RI } \\
\text { No. } 2 \text { Tahun } 2003\end{array}$ & $\begin{array}{l}\text { - Meninggalkan tugas tanpa } \\
\text { keterangan }\end{array}$ & 2 \\
\hline 2 & 29 Februari & $\begin{array}{l}\text { Pasal } 4 \text { (d) JO } 4 \text { (i) } \\
\text { PP RI No. } 2 \text { Tahun } \\
2003\end{array}$ & $\begin{array}{l}\text { - Meninggalkan tugas tanpa } \\
\text { keterangan dan minum } \\
\text { minuman keras }\end{array}$ & 1 \\
\hline 3 & 12 April & $\begin{array}{l}\text { Pasal } 3 \text { (g) JO } 5 \text { (a) } \\
\text { PP RI No. } 2 \text { Tahun } \\
2003\end{array}$ & $\begin{array}{l}\text { Meninggalkan tugas tanpa } \\
\text { keterangan dan terlibat } \\
\text { perkelahian }\end{array}$ & 1 \\
\hline 4 & 23 Mei 2014 & $\begin{array}{l}\text { Pasal } 5 \text { (a) PP RI } \\
\text { No. } 2 \text { Tahun } 2003\end{array}$ & - $\quad$ Terlibat perkelahian & 1 \\
\hline 5 & 10 Juni 2014 & $\begin{array}{l}\text { Pasal } 3 \text { (g) JO } 5 \text { (a) } \\
\text { PP RI No. } 2 \text { Tahun } \\
2003\end{array}$ & $\begin{array}{l}\text { Meninggalkan tugas tanpa } \\
\text { keterangan dan terlibat } \\
\text { perkelahian }\end{array}$ & 1 \\
\hline 6 & $\begin{array}{l}2 \text { Agustus } \\
2014\end{array}$ & $\begin{array}{l}\text { Pasal } 4 \text { (d) PP RI } \\
\text { No. } 2 \text { Tahun } 2003\end{array}$ & $\begin{array}{l}\text { - Meninggalkan tugas tanpa } \\
\text { keterangan }\end{array}$ & 1 \\
\hline 7 & $\begin{array}{l}6 \text { Agustus } \\
2014\end{array}$ & $\begin{array}{l}\text { Pasal } 3 \text { (g) dan } \\
\text { Pasal } 4 \text { (d) JO } 5 \text { (a) } \\
\text { PP RI No. } 2 \text { Tahun } \\
2003\end{array}$ & $\begin{array}{l}\text { Meninggalkan tugas tanpa } \\
\text { keterangan. Minum minuman } \\
\text { keras dan terlibat perkelahian }\end{array}$ & 1 \\
\hline
\end{tabular}

Berdasarkan data tersebut menunjukkan ketidak disiplinan anggota Polri yang masih perlu ditingkatkan.Faktor-faktor yang mempengaruhi anggota Polri dalam melakukan pelanggaran tersebut bermacam-macam.Pelanggaran disiplin oleh anggota Polri ada yang dilatarbelakangi permasalahan rumah tangga. Pertengkaran dengan istri akibat masalah ekonomi dan perbedaan pendapat. Kesibukan tugas anggota Polri sehingga waktu untuk keluarga tidak banyak. Peran anggota Polri di keluarga menjadi kurang. Konflik dalam rumah tangga memberikan tekanan pada anggota Polri sehingga menyebabkan anggota Polri tidak dapat menjalankan tugasnya dengan baik yang diantaranya dengan melakukan pelanggaran disiplin anggota Polri.

Munculnya konflik kerja-keluarga antara lain adalah banyaknya waktu yang dipakai untuk kerja (Gutek et al., 1991). Stoner dan Charles (1990) menyatakan semakin banyak waktu yang digunakan untuk bekerja maka semakin sedikit waktu untuk keluarga mengenai sehingga menyebabkan terjadinya workfamily conflict. Tugas dan tanggungjawab Polri dalam menjaga kamtibmas mengharuskan anggota Polri jarang berkumpul dengan keluarga. Kondisi tersebut 
tidak selalu dapat diantisipasi oleh anggota keluarga, sehingga dapat menimbulkan konflik dalam keluarga.

Work-Family Conflict (WFC) adalah salah satu dari bentuk interrole conflict yaitu tekanan atau ketidakseimbangan peran antara peran di pekerjaan dengan peran didalam keluarga (Greenhaus \& Beutell, 1985). Jam kerja yang panjang dan beban kerja yang berat merupakan pertanda langsung akan terjadinya konflik pekerjaan-keluarga, dikarenakan waktu dan upaya yang berlebihan dipakai untuk bekerja mengakibatkan kurangnya waktu dan energi yang bisa digunakan untuk melakukan aktivitas-aktivitas keluarga (Greenhaus \& Beutell, 1985).

Berdasarkan uraian tersebut maka tujuan penelitian ini adalah untuk mengetahui hubungan antara work-family conflict dengan disiplin kerja

\section{METODE PENELITIAN}

\section{Identifikasi Variabel Penelitian}

Penelitian ini terdiri dari dua variabel yaitu : variabel bebas (independent) dalam penelitian ini yaitu work-family conflict, variabel terikat (dependent) dalam penelitian ini yaitu disiplin kerja.

\section{Definisi Operasional}

Disiplin kerja adalah ketaatan dan kepatuhan yang sungguh-sungguh terhadap peraturan disiplin anggota Kepolisian Negara Republik Indonesia. Disiplin kerja dalam penelitian ini diukur menggunakan skala yang terdiri dari aspek pemahaman terhadap peraturan yang berlaku, kepatuhan dan ketaatan terhadap aturan standar, pemberian hukuman jika terjadi pelanggaran.

Work-family conflict yaitu tekanan atau ketidakseimbangan peran antara peran di pekerjaan dengan peran didalam keluarga. Work-family conflict dalam penelitian ini diukur menggunakan skala yang terdiri dari dimensi: Time-Based Conflict, Strain Based Conflict, Behavior Based Conflict.

\section{Populasi Dan Sampel Penelitian}

Populasi dalam penelitian ini adalah seluruh anggota Polri di Distrik Wanadadi Polres Banjarnegara yang meliputi wilayah kerja Polsek Banjarmangu, Wanadadi, Punggelan dan Polsek Rakit sebanyak 67 orang sudah berkeluarga.

\section{Metode Pengumpulan Data}

Pengumpulan data tentang work-family conflict dan disiplin kerja menggunakan skala work-family conflict dan skala disiplin kerja

\section{Validitas Dan Reliabilitas Instrumen}

Hasil uji validitas skala work-family conflict, dengan menggunakan taraf signifikansi 5\% $(\alpha=0,05)$ atau interval kepercayaan 95\%, maka diperoleh nilai $r_{\text {tabel }}=0,361$. Apabila $r_{i x}>r_{\text {tabel }}$ artinya aitem pernyataan valid. 
Berdasarkan uji validitas dari 50 item, terdapat 10 aitem pernyataanwork-family conflict gugur/tidak valid dan 40 aitem yang valid.

Hasil uji validitas skala disiplin kerja anggota Polri, dengan menggunakan taraf signifikansi 5\% ( $\alpha=0,05)$ atau interval kepercayaan 95\%, maka diperoleh nilai $r_{\text {tabel }}=0,361$. Apabila $r_{i x}>r_{\text {tabel }}$ artinya aitem pernyataan valid. Berdasarkan uji validitas dari 70 aitem, terdapat 14 aitem gugur/tidak valid dan 56 aitem yang valid.

Koefisien reliabilitas untuk skala work-family conflict adalah sebesar 0,9381 dan koefisien reliabilitas untuk skala disiplin kerja anggota Polri sebesar 0,9482 .

\section{HASIL DAN PEMBAHASAN}

Berdasarkan hasil analisis data diperoleh kesimpulan ada hubungan yang signifikan antara work-family conflict dengan disiplin kerja anggota Polri. Nilai korelasi product moment yang negatif $(-0,485)$ artinya hubungan antara workfamily conflict dengan disiplin kerja anggota Polri bersifat negatif. Dengan demikian, jika work-family conflict makin tinggi, makadengan disiplin kerja anggota Polri akan rendah dan sebaliknya jika work-family conflict makin rendah, makadengan disiplin kerja anggota Polri akan tinggi.

Work-Family Conflict (WFC) adalah salah satu dari bentuk interrole conflict yaitu tekanan atau ketidakseimbangan peran antara peran di pekerjaan dengan peran didalam keluarga (Greenhaus \& Beutell, 1985). Jam kerja yang panjang dan beban kerja yang berat merupakan pertanda langsung akan terjadinya konflik pekerjaan-keluarga (WFC), dikarenakan waktu dan upaya yang berlebihan dipakai untuk bekerja mengakibatkan kurangnya waktu dan energi yang bisa digunakan untuk melakukan aktivitas-aktivitas keluarga (Greenhaus \& Beutell, 1985).

Work-family conflict yang berhubungan dengan disiplin kerja anggota Polri, menunjukkan harus ada upaya kongkrit yang dilakukan untuk meminimalisir terjadinya konflik dalam keluarga dan pekerjaan. Anggota Polri pada saat menghadapi masalah di rumah, sebaiknya dapat segera mengatasinya dengan baik agar tidak terbawa di tempat kerja. Anggota Polri harus dapat membagi peran sebagai kepala keluarga dan sebagai anggota Polri, sehingga dapat meminimalkan terjadinya work-family conflict.

Berdasarkan deskripsi data penelitian diketahui gambaran work-family conflict yaitu $0,0 \%$ (0 subjek) memiliki work-family conflict sangat tinggi, 31,3\% (21 subjek) memiliki work-family conflict tinggi, 36,1\% (28 subjek) memiliki work-family conflict sedang, 20,9 \% (14 subjek) memiliki work-family conflict rendah. dan $6,0 \%$ (4 subjek) memiliki work-family conflict sangat rendah.

Penelitian yang dilakukan oleh Yuliana dan Yuniasanti (2013) mendapatkan hasil bahwa subjek penelitian yang memiliki konflik pekerjaankeluarga tinggi sebanyak 1 orang $(3,125 \%)$, yang memiliki konflik pekerjaan- 
keluarga sedang sebanyak 28 orang $(87,5 \%)$, dan yang memiliki konflik pekerjaan-keluarga rendah sebanyak 3 orang $(9,375 \%)$, hal ini menunjukan bahwa anggota keluarga yang memiliki peran ganda yaitu sebagai anggota keluargga dan sebagai karyawan memiliki kecenderungan untuk terjadi konflik di dalam rumah tangga.

Jam kerja yang panjang dan beban kerja yang berat merupakan pertanda langsung akan terjadinya konflik pekerjaan-keluarga (WFC), dikarenakan waktu dan upaya yang berlebihan dipakai untuk bekerja mengakibatkan kurangnya waktu dan energi yang bisa digunakan untuk melakukan aktivitas-aktivitas keluarga (Greenhaus \& Beutell, 1985).

Work-family conflict yang sebagian besar pada kategori sedang bisa disebabkan karena anggota Polri yang harus selalu siap 24 jam untuk menjalankan tugas yang diberikan pimpinan. Jika kondisi tersebut tidak dapat diatasi oleh anggota Polri, maka dapat menimbulkan work-family conflict yang berdampak pada menurunnya disiplin kerja anggota Polri.

Gambaran disiplin kerja anggota Polri, yaitu 0,0 \% (0 subjek) memiliki disiplin kerja sangat tinggi, 35,8 \% (24 subjek) memiliki disiplin kerja tinggi, 38,8 $\%$ (26 subjek) memiliki disiplin kerja sedang, 19,4 \% (13 subjek) memiliki disiplin kerja rendah dan 6,0\% (4 subjek) memiliki disiplin kerja kategori sangat rendah.

Penelitian yang dilakukan oleh Wijayanto (2010) menyimpulkan masih adanya anggota Polri yang kurang mentaati peraturan perundang-undangan atau kode etik profesi. Data jumlah nggota Polri yang melakukan pelanggaran disiplin secara nasional dari tahun 2005 - 2007 mencapai 9.068 orang yang terdiri dari Pati 12 orang, Pamen 236 orang, Pama 865 orang, Bintara 7.574 orang dan Tamtama 373 orang, hal tersebut menunjukan bahwa masih tingginya ankga pelanggaran disiplin di lingkungan Kepolisian.

Disiplin kerja anggota Polri yang sebagian besar pada kategori sedang disebabkan karena padatnya tugas polisi dan juga karena adanya anggota Polri yang rumahnya cukup jauh dari tempat kerja. Hal ini bisa menyebabkan anggota Polri tidak selalu dapat datang di tempat kerja tepat waktu untuk melaksanakan tugas yang diberikan pimpinan.

Disiplin kerja anggota Polri yang tinggi sangat diperlukan agar dapat melaksanakan tugas di bidang kamtibmas dengan baik. Disiplin kerja yang rendah bisa menyebabkan anggota Polri tidak dapat melaksanakan tugasnya dengan baik, sehingga di masyarakat banyak terjadi gangguan kamtibmas.

Anggota Polri memiliki peraturan kerja yang harus dipatuhi oleh seluruh anggota Polri yang diatur di dalam peraturan perundang-undangan. Oleh karena itu, tindakan tidak disiplin yang dilakukan oleh anggota Polri dapat diberikan 
sanksi sesuai dengan ketentuan yang diatur dalam undang-undang. Peraturan disiplin anggota Kepolisian Negara Republik Indonesia tertuang dalam Peraturan Pemerintah Republik Indonesia Nomor 2 Tahun 2003 Tentang Peraturan Disiplin Anggota Kepolisian Negara Republik Indonesia.

\section{KESIMPULAN}

Terdapat hubungan work-family conflict dengan disiplin kerja anggota Polri Distrik Wanadadi Polres Banjarnegara. Hubungan antara work-family conflict dengan disiplin kerja dalam arah negatif, artinya jika work-family conflict meningkat, maka disiplin kerja anggota Polri akan menurun, sebaliknya jika workfamily conflict menurun, maka disiplin kerja anggota Polri akan meningkat.

\section{DAFTAR PUSTAKA}

Gomes, F. C. (2000). Manajemen Sumber Daya Manusia. Yogyakarta; Andi Offset

Greenhaus, J. H., \& Beutell, N. J. (1985). Sources of conflict between work and family roles. Academy of Management Review, 10 (1), 76-88.

Gutek, B. A., Searle, S., \& Klepa, L. (1991).Rational Versus Gender Role Explanations for Work-Family Conflict. . Journal of Applied Psychology, 76 (4), 560-568.

Sastrohadiwiryo, S. B. (2001). Manajemen Tenaga Kerja Indonesia : Pendekatan Administrasi dan Operasional. Jakarta: Bumi Aksara.

Sinungan, M. (2000). Produktivitas : Apa dan Bagaimana, Jakarta: Bumi Aksara.

Stoner, A.F. \& Charles, R. (1990). Work-Home role conflict in female owners of small business: an exploratory study. Journal of small business management, 28 (1).

Wijayanto, A. (2010). Strategi Penegakan Hukum Disiplin Anggota Polri Guna Mewujudkan Good Governance Dan Clean Government Di Internal Polri Dalam Rangka Memantapkan Citra Polri. (Tesis, tidak diterbitkan). Universitas Diponegoro, Indonesia. 